\title{
Seventeen years after BRCA1: what is the BRCA mutation status of the breast cancer patients in Africa? - a systematic review
}

\author{
Lawal AbdulRazzaq Oluwagbemiga ${ }^{\text {* }}$, Atoyebi Oluwole ${ }^{1}$ and Adesunkanmi AbdulRasheed Kayode ${ }^{2}$
}

\begin{abstract}
With the discovery of the BRCA1 gene and other genetic mutations associated with breast cancer, it has been established that hereditary mutations account for up to $5 \%$ of patients presenting with breast cancer.

We performed a systematic review of English Language Literature to determine the role of BRCA1 and BRCA2 gene mutations in African breast cancer patients. PUBMED and AJOL database were searched for publications addressing Breast Cancer and BRCA1 and BRCA2 genes. PUBMED was searched using the following words in various combinations; 'Breast Cancer', 'BRCA1', 'BRCA2', 'BRCA', 'Genes', 'Cancer Genes', and 'Africa'.

16 studies fulfilled the study criteria up till December 2011. The studies were from North Africa (NA) and Sub-Saharan Africa (SSA).

A total of 9 studies were found evaluating 752 (352 repeated Zhang J (2010)) patients from SSA. Three studies (144 patients) evaluated all the coding regions of both BRCA1 and BRCA2 while 2 studies (571 patients) evaluated part(s) of BRCA1 and one (20 Patients) evaluated part(s) of BRCA2, one re-evaluated the whole of the BRCA1 gene in a previous sub-set of patients, while one (16 patients) evaluated parts of both BRCA1 and BRCA2.

In North Africa, 6 studies evaluated 374 patients, with 4 studies (219 patients) evaluating the whole of the BRCA1 and BRCA2 genes while two (155 patients) studies evaluated only parts of both BRCA1 and BRCA2, with one of the studies evaluating the whole of the BRCA1 gene in a subset (24 patients).

Due to this paucity of well powered population based studies evaluating the influence of BRCA genetic mutations in breast cancer patients in Africa, there is a need to perform well powered studies and population screening to determine the impact of germ line mutations in the Breast Cancer patient in Africa before any categorical statements can be made with respect to their BRCA status.
\end{abstract}

Keywords: Breast cancer, Gene mutations, Africa, BRCA1, BRCA2, Systematic review

\section{Introduction}

\section{Epidemiology of breast cancer}

Breast cancer is the most common malignancy affecting women worldwide. According to GLOBOCAN there were 1.38 million new cases of breast cancer in the world in 2008 , with a corresponding mortality of 458,000 . In Africa, over the same time period, there were 68,000 new cases with 37,000 deaths documented, although this probably represents a gross underestimation due to incomplete case ascertainment and reporting Adesunkanmi et al.

\footnotetext{
* Correspondence: razzaklawal@yahoo.com

'Department of Surgery, College of Medicine of the University of Lagos, Lagos, Nigeria

Full list of author information is available at the end of the article
}

(2006). In 2010, the World Health Organisation (WHO) estimated that there would be 97,743 new breast cancer cases in Africa, with an estimated mortality of 52,855 IARC (2011).

The reportedly lower incidence of breast cancer in Africa may be explained by lower life expectancy, incomplete record keeping and paucity of epidemiological studies and incomplete case ascertainment. In addition, peculiarities in the presentation of breast cancer in Africa may limit detection Adesunkanmi et al. (2006). These include an apparently younger age and later stage at presentation with more aggressive tumour characteristics Adesunkanmi et al. (2006). The late presentation which may be a consequence 
of poor health seeking behaviour is also compounded by the more aggressive nature of breast cancer in Africa.

The cause(s) of breast cancer remain largely unknown, though several risk factors have been characterised. The most important factors are the age of the patient and the effect of female sex hormones. Thus early menarche, late menopause and nulliparity all confer an increased risk of breast cancer. Breast feeding is noted to be protective while ingestion of exogenous female sex hormones is a risk factor for breast cancer.

A positive family history of breast cancer is known to increase the risk of breast cancer. However, it was only in 1990, based on the results of linkage analysis performed by Hall et al. (1990) that firm evidence was provided for the existence of at least one hereditary breast cancer gene. Miki et al described the first germ line mutation known to confer increased risk of breast cancer in 1994, labelled BRCA1 Miki et al. (1994). Shortly thereafter, a second germ line mutation associated with increased risk was also identified and named BRCA2 Wooster et al. 1995). Subsequently, several susceptibility genes have been associated with breast cancer. These genes confer 'high-risk' and 'low to moderate risk' of breast cancer. The high-risk breast cancer susceptibility genes include BRCA1, BRCA2, PTEN, TP53, LKB1/STK11 and CDH1, with relative lifetime risks higher than 4 (but generally much higher at young ages). The CHEK2, TGF 1 1, CASP8 and $A T M$ genes belong to the 'low to moderate-risk' breast cancer susceptibility genes Oldenburg et al. (2007).

BRCA1 mutation carriers have a $30 \%$ risk of developing ovarian cancer during their lifetime Whittemore et al. (1997) and a 50-80\% risk of developing breast cancer before the age of 70 years Deng (2006). BRCA1 is mapped to chromosome 17q21 Adesunkanmi et al. (2006); it contains 24 exons and encodes a protein of $220 \mathrm{kDa}$, composed of 1863 amino acids Chen et al. (1996). The second breast cancer susceptibility gene, BRCA2, is localized on the long arm of chromosome 13. BRCA2 is also a large gene, with 27 exons that encode a protein of $380 \mathrm{kDa}$, composed of 3418 amino acids Bertwistle et al. (1997).

Risk-associated truncation mutations are found throughout the entire BRCA1 coding sequence Linger \& Kruk (2010). The majority of risk-associated mutations are frameshift or nonsense mutations that result in a premature stop codon and truncated protein product (NIH Breast Cancer Information Core Database, http://research.nhgri. nih.gov/bic/). Both BRCA1 and BRCA2 are thought to act as classical tumour suppressor genes and the loss of their cellular functions is thought to occur through bi-allelic inactivation. Carriers of mutations have one germline hit (the inherited mutated copy of BRCA1) and, in the tumour, a second somatic hit usually through the loss of heterozygosity Deng (2006; Collins et al. 1995).
A determination of BRCA genetic mutational status will go a long way towards advice on prophylaxis for breast cancer. The data on BRCA gene mutations in Africans is sparse. The mutational spectrum of BRCA1/ 2 in African Americans has not been as well characterized as that of Caucasians Ferla et al. (2007).

The knowledge base about the various genetic mutations in the BRCA genes of people of African origin is scattered in diverse small pockets of articles. The aim of this study is to collate all these data and present them in a single review in order to better characterise the genetic mutational spectrum of the indigenous African people.

\section{Method}

Data on breast cancer genetics in Africans was obtained via a literature search. The key words were "Breast Can$c e r$ " and "Africa" with "Genes", "BRCA Genes", "BRCA1" and "BRCA2" in different combinations. The databases searched were PubMed, African Journals Online (AJOL), the WHO HINARI database, and Ptolemy (University of Toronto library). Only articles published in English were included. References of relevant articles were also reviewed for additional literature. Studies combining and/or comparing Africans with other ethnicgroups were included but only the data of the Africans analysed were included in this review. Studies done outside Africa but which studied an indigenous African people were included.

Specific information retrieved were: type of study, number of exons evaluated, number, type and classification of mutations.

\section{Result}

\section{BRCA1 and BRCA 2 mutations}

Sub Saharan African (SSA)

In 1997, Stoppa-Lyonnet Stoppa-Lyonnet et al. (1997) evaluated the whole of the BRCA 1 gene and reported a case of frameshift truncating BRCA1 mutation (926ins10) in a Breast Ovarian Cancer family from Ivory Coast.

Yawitch et al. (2000) evaluated 206 black South African women for 185delAG in exon 2, 4184del4, 943ins10 and 1832deI5 in exon 11, and 5382insC in exon 20, and Met1775Arg in exon 21 mutations in BRCA1. Eleven of these patients had a family history of Breast cancer. None of these mutations were found in any of the patients studied.

Gao Q et al. (2000) screened 70 young African breast cancer patients with early onset breast cancer in Ibadan, Nigeria. Only one of the patients had a family history of breast cancer. All the regions of the BRCA1 and BRCA2 genes were analysed. Eighteen (23\%) of the patients had mutations. Three truncating mutations (2 BRCA1 and 1 BRCA2) were detected. Twenty four non truncating mutations (4 BRCA1 and 20 BRCA2) were also detected in this cohort. 
Fackenthal et al. (2005) studied 39 Early onset breast cancer $(\leq 40$ years) patients in Nigeria. Twenty nine (74\%) patients carried a genetic variation in BRCA1 (4 variants), BRCA2 (30 variants) or both genes. However, they found only 1 (3034del4) truncating mutation located on exon 11 of BRCA2. The rest were either unclassified variants or polymorphisms. They went further to test the clinical significance of their finding by examining the BRCA genes of 74 unaffected Nigerians. Five of 13 BRCA2 variations expected to result in deleterious amino acid substitutions were not found in the controls.

A truncating mutation in BRCA1 (Y101X (422 T > G), exon 7) previously identified in Nigerian Breast Cancer patients led Zhang et al. (2009) to screen 365 Nigerian women with Breast cancer and 177 controls for this mutation. This genetic mutation was further discovered in 3 other unrelated patients. All the patients were of the Yoruba ethnic group.

Masri et al. (2002) studied 20 unselected breast cancer patients in Sudan. They analysed Exon 11 of the BRCA2 gene and exon 5-9 of the p53 codon. Four of the patients had a family history of Breast carcinoma, while 1 of the patients - with a family history - had bilateral disease. They found only 1 somatic mutation and 1 polymorphism. They however did not elaborate on the type of mutation and/or the base pairs involved.

Awadelkarim et al. (2007) studied 34 Early onset $(\leq 40$ years) and 1 Male Breast Cancer patient in central Sudan. All the coding regions of BRCA1 and BRCA2 were analysed. Majority of the patients (33/35) had mutations. They found 5 truncating mutations ( 2 in BRCA1, 3 in BRCA2) in 5 patients, one of which, (BRCA2) was in the male patient. They also found 55 unclassified variants (30 in BRCA1, 25 in BRCA2), 5 of which were predicted to affect protein function.

Zhang et al. (2010) evaluated 352 patients from Nigeria previously determined not to have any germline mutations for either BRCA1 or BRCA2 for large genomic rearrangement (LGR). Multiplex ligation-dependent probe amplification (MLPA) was used to screen BRCA1 rearrangements in these patients. They found only 1 patient with a deletion of exon 21 .

van der Merwe et al. (2010) screened 16 Black Xhosa patients with breast cancer referred for genetic testing for 6 founder mutations (3 Ashkenazi and 3 Afrikaner). None of these patients carried any of these common founder mutations. They found a mutation on exon 11 of the BRCA2 gene. They then went ahead to screen exon 10 of BRCA1 and exon 10 \& 11 of BRCA2. Four of the Xhosa women were found to have a BRCA2 mutation on exon 11. This mutation was also found to be present in 4 out of 105 Colored patients referred for genetic testing.

\section{North African (NA)}

Balci et al. (1999) evaluated BRCA1 and BRCA2 in Turkish breast and ovarian cancer patients with a strong family history of breast cancer in 1999. The whole of the genes were evaluated. In this group of 15 Families of 33 patients, three deleterious mutations (2 BRCA1 and 1 BRCA2) were detected. The BRCA2 mutation was detected in one of the male breast cancer patients.

Ozdag et al. (2000) in 2000 published a study on 50 high risk Turkish Breast cancer patients. Patients were selected based on four criteria; early age at onset, male breast cancer, hereditary breast cancer and familial breast cancer. Exons 2, 5, 11 (10 overlapping fragments), 13, 20 \& 24 of BRCA1, and exon 11 (7 overlapping fragments) of BRCA2 were analysed. Four deleterious mutations were found. There were 2 (BRCA2) mutations in the patients with hereditary breast cancer. The other 2 (BRCA1) mutations were found in patients with early onset breast cancer. One of these patients had 2 mutant alleles. There was no truncating mutation discovered in the male breast cancer group. There were 5 BRCA 1 sequence variants detected in 23 other patients.

In another Turkish study, Yazici et al. (2000) found 8 BRCA1 and 2 BRCA 2 mutations in 11 out of a cohort of 105 patients with breast or ovarian cancer. One (1) of the mutations was found only in an ovarian cancer patient and will not be part of the summary. Half of the patients had a family history while the remaining half had early onset breast cancer ( $\leq 50$ years). Their analysis was initially limited to exon $1 \overline{1}$ of both genes and exon 10 of BRCA2. They also performed complete analysis of the BRCA1 gene in a subset of 24 patients and found further mutations in exons 14 and 20, one of which was the Askenazi Jewish mutation 5382insC. This led them to do a heteroduplex analysis of exons 2, 14 and 20 of the BRCA1 gene in all the patients. There was a higher incidence of BRCA mutations (7 BRCA1 and 1 BRCA2) in patients with a family history. Five truncating mutations were identified in exon 11 of both genes. The remaining mutations were in exon 2, 14, 20 and intron 14 .

Uhrhammer et al. (2008) performed a study to determine the contribution of BRCA1 mutations to breast cancer in Algeria. The patient population (64) was selected on account of a family history of Breast cancer (13) and early onset Breast cancer (51) ( $\leq 38$ yrs). They evaluated the whole of the BRCA1 gene. A total of 7 deleterious mutations were found in 11 patients representing 9 families. One of these mutations was found in a patient with early onset breast cancer and another patient with familial breast cancer. Another mutation was found in 2 different families with familial breast cancer.

Troudi et al. (2007) in Tunisia studied 36 patients with family history of breast or ovarian cancer. All of the BRCA1 and BRCA2 genes were analyzed. They found 6 
Table 1 Summary of number patients and studies

\begin{tabular}{|c|c|c|c|c|c|c|}
\hline Study & Total Pt & Family $\mathrm{Hx}$ & Young & Control & BRCA1 & BRCA2 \\
\hline \multicolumn{7}{|c|}{ SUB-SAHARAN AFRICA } \\
\hline Yawitch & 206 & 11 & 0 & 0 & 00 & 0 \\
\hline Gao & 70 & 1 & 70 & 0 & 2 & 1 \\
\hline Fackenthal & 39 & 1 & 39 & 74 & 1 & 0 \\
\hline Zhang B & 365 & \multicolumn{2}{|c|}{ UNSELECTED } & 177 & 1 & \\
\hline Masri & 20 & \multicolumn{2}{|l|}{4} & & & 1 \\
\hline Awadelkarim & 35 & \multirow[t]{2}{*}{ (1Male) } & 34 & 0 & 2 & 3 \\
\hline Zhang J & 352 & & & & & \\
\hline Stoppa Lyonnet & $\mathrm{NI}$ & \multicolumn{2}{|l|}{1} & & 1 & \\
\hline Van der Merwe & 16 & \multirow{2}{*}{\multicolumn{2}{|c|}{16}} & & & \\
\hline TOTAL & 752 & & & & & \\
\hline \multicolumn{7}{|c|}{ NORTH AFRICA } \\
\hline Balci & 33 & 33 (3 Male) & 0 & 0 & 0 & 0 \\
\hline Ozdag & 50(10 Male) & 13 & 27 & 0 & & \\
\hline Yazici & 105 & 53 & 52 & 0 & 7 & 2 \\
\hline Urhammer & 64 & 13 & 51 & & & \\
\hline Troudi & 36 & 36 & & & & \\
\hline Cherbal & 86 & & & & & \\
\hline Mahfoudh et al. (2011) & 24 & & & & 4 & \\
\hline TOTAL & 398 & & & & & \\
\hline GRAND TOTAL & 1150 & & & & & \\
\hline
\end{tabular}

Table 2 Exon(s)/mutations evaluated

\begin{tabular}{|c|c|c|}
\hline STUDY & BRCA1 & BRCA2 \\
\hline Yawitch & $\begin{array}{l}\text { 185delAG in exon 2, 4184del4, 943ins } 10 \text { and } 1832 \text { del5 in exon } \\
11 \text {, and 5382insC in exon 20, and Met1775Arg in exon } 21\end{array}$ & NONE \\
\hline Gao & ALL & ALL \\
\hline Fackenthal & ALL & ALL \\
\hline Zhang B & Y101X (422 T[G), exon 7 & NONE \\
\hline Masri & NONE & Exon 11 \\
\hline Awadelkarim & ALL & ALL \\
\hline Zhang J & ALL & NONE \\
\hline Stoppa Lyonnet & $? ?$ & $? ?$ \\
\hline \multirow[t]{2}{*}{ Van der Merwe } & 185delAG, 5382insC, 1493delC, 2760 G > T, Exon 10 & Exon $10 \& 11,6174$ delT, 8162 delG \\
\hline & NORTH AFRICA & \\
\hline \multicolumn{3}{|l|}{ Balci } \\
\hline Ozdag et al. (2000) & $2,5,11$ (10 overlapping fragments), 13, 20, 24 & 11 (7 overlapping fragments) \\
\hline Yazici & $2,11,14,20$ (ALL in a subset of patients) & 10,11 \\
\hline Uhrhammer et al. (2008) & ALL & NONE \\
\hline Troudi et al. (2007) & ALL & ALL \\
\hline Cherbal F (2010) & ALL & ALL \\
\hline Mahfoudh et al. (2011) & ALL & \\
\hline
\end{tabular}


Table 3 Mutation(s) detected

\begin{tabular}{|c|c|c|c|c|c|}
\hline STUDY & EXON & MUTATION & EFFECT & CARRIERS & POPULATION \\
\hline \multicolumn{6}{|c|}{$\underline{B R C A 1}$} \\
\hline \multicolumn{6}{|c|}{ SUB SAHARAN AFRICA } \\
\hline Masri & & & NOT STUDIED & & \\
\hline Yawitch & & & NONE & & \\
\hline Van der Merwe & & & NONE & & \\
\hline Fackenthal et al. (2005) & & & NONE & & \\
\hline Yazici & 2 & 185 ins A & & & \\
\hline Cherbal F(2010) & 2 & Deletion of Exon 2 & & & \\
\hline Cherbal et al. (2010) & 3 & c.83_84delTG & & & \\
\hline Cherbal et al. (2010) & 5 & c. $181 \mathrm{~T}>\mathrm{G}$ & & & \\
\hline Troudi et al. (2007) & 5 & 330 dup A & & & \\
\hline Zhang B & 7 & Y101X (422 T[G) & & 3 & $365(177)$ \\
\hline Cherbal et al. (2010) & 8 & Deletion of Exon 8 & & & \\
\hline Gao et al. (2000) & 11 & Q1090X & Stop & 1 & 70 \\
\hline Gao et al. (2000) & 11 & 1742insG & Frameshift & 1 & 70 \\
\hline Stoppa Lyonnet & 11 & 926 ins 10 & & 1 & \\
\hline \multirow[t]{3}{*}{ Yazici } & 11 & 1623delTTAAA & & & \\
\hline & 11 & 2139delC & & & \\
\hline & 11 & 3819delGTAAA & & & \\
\hline \multirow[t]{2}{*}{ Ozdag } & 11 & 1201 ins $A$ & & & \\
\hline & 11 & K654E & & & \\
\hline \multirow[t]{2}{*}{ Troudi et al. (2007) } & 11 & 4160 delAG & & & \\
\hline & 11 & 2789 del G & & & \\
\hline Cherbal et al. (2010) & 11 & c.798_799delTT & & & \\
\hline Stoppa-Lyonnet et al. (1997) & 11 & 926 ins 10 & Frameshift & 1 & $(? 160)$ \\
\hline Gao et al. (2000) & 11 & $3034 / 6$ del4 & Frameshift & 1 & 70 \\
\hline Fackenthal et al. (2005) & 11 & 3034/6 delACAA & & & \\
\hline Masri & 11 & Not Indicated & & & \\
\hline \multirow[t]{2}{*}{ Yazici } & 14 & 4508delC & & & \\
\hline & Int 14 & IVS-14+1delG & & & \\
\hline Balci et al. (1999) & 20 & 5382insC & Stop & & \\
\hline Yazici & 20 & 5382insC & & & \\
\hline Troudi et al. (2007) & 20 & 5385ins C & & & \\
\hline Zhang et al. (2010) & 21 & Deletion of Exon 21 & & 1 & \\
\hline Balci et al. (1999) & 24 & $5622 C-T$ & Stop & & \\
\hline Awadelkarim KD(2007) & $\mathrm{Nl}$ & c.3999delT & Stop (codon 1335) & & \\
\hline Awadelkarim et al. (2007) & & c.4065_4068delTCAA & Stop (codon 1364) & & \\
\hline \multirow[t]{7}{*}{ Uhrhammer et al. (2008) } & & c.46_74del29 & & & \\
\hline & & c.83_84delTG & & & \\
\hline & & c. $202+1 \mathrm{G}>\mathrm{A}$ & & & \\
\hline & & c.798_799delTT & & & \\
\hline & & c.1817delC & & & \\
\hline & & c.2745dupT & & & \\
\hline & & c.3715delT & & & \\
\hline
\end{tabular}


Table 3 Mutation(s) detected (Continued)

\begin{tabular}{|c|c|c|c|}
\hline Yawitch & & & NONE \\
\hline Zhang B & & & NONE \\
\hline ZHANG J & & & NONE \\
\hline Stoppa Lyonnet & & & NONE \\
\hline Urhammer & & & NONE \\
\hline Troudi et al. (2007) & 10 & 1537 del 4 & \\
\hline Cherbal et al. (2010) & 10 & c.1310_1313delAAGA & \\
\hline van der Merwe et al. (2010) & 11 & 5999del4 (?Founder) & Frameshift \\
\hline Balci et al. (1999) & 11 & 3414delTCAG & Stop \\
\hline \multirow[t]{2}{*}{ Ozdag } & 11 & 3034 delAAAC & \\
\hline & 11 & 6880 ins & \\
\hline Yazici et al. (2000) & 11 & 5295insA & \\
\hline Yazici et al. (2000) & 11 & 6656delC & \\
\hline Troudi et al. (2007) & 11 & 5909 ins A & \\
\hline Cherbal et al. (2010) & 11 & c.5722 5723delCT & \\
\hline Awadelkarim et al. (2007) & & c.3195_3198delTAAT & Stop (codon 1075) \\
\hline Awadelkarim et al. (2007) & & c.6406_6407delTT & Stop (codon 2139) \\
\hline Awadelkarim et al. (2007) & & c.8642_8643insTाT & Stop (codon 2907) \\
\hline
\end{tabular}

$\mathrm{NI}=$ Not Indicated, $\infty$ ? Same patient as Gao.

deleterious mutations in 7 patients. Four of these were in BRCA1 (5 patients) and the remainder were in BRCA2 (2 patients). In addition to these mutations, nine distinct unclassified sequence variants ( 8 in BRCA1 and 1 in BRCA2) and 16 distinct polymorphisms (12 in BRCA1 and 4 in BRCA2) were identified.

Cherbal et al. (2010) studied 86 high risk individuals male breast cancer, strong family history of breast, ovarian and/or prostate cancers - from 70 families. All the regions of the BRCA1 and BRCA2 genes were evaluated for mutations. Individuals were screened by HighResolution Melting (HRM) curve analysis followed by direct sequencing. Samples for which no pathogenic mutation was found were analyzed by MLPA. Three pathogenic mutations in $B R C A 1$ gene and two within $B R C A 2$ gene were detected using PCR and HRM. Using MLPA, a novel deletion of BRCA1 exon 2 and a deletion of BRCA1 exon 8 were identified in two patients with breast/ovarian cancer and bilateral breast cancer, respectively. The mutations occurred in 8 of 70 families.

Mahfoudh et al. (2011) studied 24 patients in 16 breast/ ovarian cancer families. All the coding regions of the BRCA1 gene were analysed. Six families had four deleterious mutations one of which (IVS5 + 2insG) was novel. Another of the mutations (916delTT) was noted in 3 apparently unrelated families.

Tables 1, 2, 3 show a summary of the studies, the portion(s) of the gene(s) evaluated in each study and the mutation(s) detected.

\section{Discussion}

Throughout the continent of Africa, over a seventeen year period, 16 studies have evaluated 1150 patients for mutations in the BRCA1 and/or BRCA2 genes in breast cancer patients. Seven hundred and fifty two from SSA and 398 from NA. Four studies evaluated parts of BRCA1 \& 2 in 171 patients, 5 studies evaluated the whole of the BRCA1 gene in 465 patients, 6 studies evaluated all the regions of both genes in 299, while 2 studies evaluated parts of BRCA1 in 571 and 1 study evaluated part of BRCA2 in 20 patients.

In this period, the evaluation of genetic mutations in African breast cancer patients has improved from the anecdotal reports of Stoppa-Lyonnet and the evaluation of specific mutations by Yawitch to the discovery of LGRs by Zhang.

In the African breast cancer patients studied, LGRs were found rarely. In some areas, LGRs were also rare in breast and ovarian cancer families de la Hoya et al. (2006; Engert et al. 2008). This contrasts with other areas of the world where Genomic rearrangements account for more than one-third of the brca1 mutations in northern Italian breast/ovarian cancer families Montagna et al. (2003).

\section{Conclusion}

In spite of the lower age at presentation and more aggressive nature of breast cancer in African patients and the association of genetic mutations with breast cancer in young women, there has been a paucity of studies evaluating the 
genetic basis of breast cancer in this patient population. Evaluation of only 1,150 patients in a disease with a 5 year prevalence of 302,310 at a rate of less than one (1) study per year since the discovery of the BRCA gene is less than adequate. Most of the studies did not evaluate all the coding regions of the genes. Some of them only examined either BRCA1 or BRCA2. Some mutations were found and documented. However, the clinical significance of some of the germ line mutations identified and the clinical application is yet to be confirmed. This is because these studies were grossly underpowered to make any far reaching conclusion about the genetics of the African patient with Breast Cancer. There is therefore a need to perform well powered studies and population screening to determine the impact of germ line mutations in the African Breast Cancer patient.

\section{Competing interests}

The authors declare that they have no competing interests.

\section{Authors' contributions}

AOL: Conception and Design, Data search and retrieval of Articles, Prepared initial Draft of manuscript. OA: Conception and Design, Reviewed initial draft. AARK: Conception and design, Reviewed Initial draft. All authors read and approved the final manuscript.

\section{Author details}

'Department of Surgery, College of Medicine of the University of Lagos, Lagos, Nigeria. ${ }^{2}$ Department of Surgery, College of Health Sciences, Obafemi Awolowo University, lle Ife, Nigeria.

Received: 9 December 2012 Accepted: 20 December 2012 Published: 28 December 2012

\section{References}

Adesunkanmi AR, Lawal OO, Adelusola KA, Durosimi MA (2006) The severity, outcome and challenges of breast cancer in Nigeria. Breast 15(3):399-409. doi:S0960-9776(05)00140-2[pii].10.1016/j.breast.2005.06.008

Awadelkarim KD, Aceto G, Veschi S, Elhaj A, Morgano A, Mohamedani AA, Eltayeb EA, Abuidris D, Di Gioacchino M, Battista P, Verginelli F, Cama A, Elwali NE, Mariani-Costantini R (2007) BRCA1 and BRCA2 status in a Central Sudanese series of breast cancer patients: interactions with genetic, ethnic and reproductive factors. Breast Cancer Res Treat 102(2):189-199. doi:10.1007/ s10549-006-9303-z

Balci A, Huusko P, Paakkonen K, Launonen V, Uner A, Ekmekci A, Winqvist R (1999) Mutation analysis of BRCA1 and BRCA2 in Turkish cancer families: a novel mutation BRCA2 3414del4 found in male breast cancer. Eur J Cancer 35(5):707-710. doi:S0959804999000143[pii]

Bertwistle D, Swift S, Marston NJ, Jackson LE, Crossland S, Crompton MR, Marshall CJ, Ashworth A (1997) Nuclear location and cell cycle regulation of the BRCA2 protein. Cancer Res 57(24):5485-5488

Chen Y, Farmer AA, Chen CF, Jones DC, Chen PL, Lee WH (1996) BRCA1 is a 220$\mathrm{kDa}$ nuclear phosphoprotein that is expressed and phosphorylated in a cell cycle-dependent manner. Cancer Res 56(14):3168-3172

Cherbal F, Bakour R, Adane S, Boualga K, Benais-Pont G, Maillet P (2010) BRCA1 and BRCA2 germline mutations screening in Algerian breast/ovarian cancer families. Dis Markers 28(6):377-384. doi:BU18P1H3N800291V[pii].10.3233/ DMA-2010-0718

Collins N, McManus R, Wooster R, Mangion J, Seal S, Lakhani SR, Ormiston W, Daly PA, Ford D, Easton DF et al (1995) Consistent loss of the wild type allele in breast cancers from a family linked to the BRCA2 gene on chromosome 13q12-13. Oncogene 10(8):1673-1675

de la Hoya M, Gutierrez-Enriquez S, Velasco E, Osorio A, Sanchez de Abajo A, Vega A, Salazar R, Esteban E, Llort G, Gonzalez-Sarmiento R, Carracedo A, Benitez J, Miner C, Diez O, Diaz-Rubio E, Caldes T (2006) Genomic rearrangements at the BRCA1 locus in Spanish families with breast/ovarian cancer. Clin Chem 52(8):1480-1485. doi:Clinchem.2006.070110[pii] S0007092000913326[pii]

Deng CX (2006) BRCA1: cell cycle checkpoint, genetic instability, DNA damage response and cancer evolution. Nucleic Acids Res 34(5):1416-1426. doi:34/5/ 1416[pii]10.1093/nar/gk1010

Engert S, Wappenschmidt B, Betz B, Kast K, Kutsche M, Hellebrand H, Goecke TO, Kiechle M, Niederacher D, Schmutzler RK, Meindl A (2008) MLPA screening in the BRCA1 gene from 1,506 German hereditary breast cancer cases: novel deletions, frequent involvement of exon 17, and occurrence in single earlyonset cases. Hum Mutat 29(7):948-958. doi:10.1002/humu.20723

Fackenthal JD, Sveen L, Gao Q, Kohlmeir EK, Adebamowo C, Ogundiran TO, Adenipekun AA, Oyesegun R, Campbell O, Rotimi C, Akang EE, Das S, Olopade OI (2005) Complete allelic analysis of BRCA1 and BRCA2 variants in young Nigerian breast cancer patients. J Med Genet 42(3):276-281. doi:42/3/ 276[pii].10.1136/jmg.2004.020446

Ferla R, Calo V, Cascio S, Rinaldi G, Badalamenti G, Carreca I, Surmacz E, Colucci G, Bazan V, Russo A (2007) Founder mutations in BRCA1 and BRCA2 genes. Ann Oncol 18(Suppl 6):vi93-vi98. doi:18/suppl_6/vi93[pii].10.1093/annonc/ $\mathrm{mdm} 234$

Gao Q, Adebamowo CA, Fackenthal J, Das S, Sveen L, Falusi AG, Olopade OI (2000) Protein truncating BRCA1 and BRCA2 mutations in African women with pre-menopausal breast cancer. Hum Genet 107(2):192-194

Hall JM, Lee MK, Newman B, Morrow JE, Anderson LA, Huey B, King MC (1990) Linkage of early-onset familial breast cancer to chromosome 17q21. Science 250(4988):1684-1689

IARC (2011) GLOBOCAN 2008 Cancer Incidence, Mortality and Prevalence Worldwide in 2008. World Health Organisation, http://globocan.iarc.fr/ factsheet.asp. Accessed 31st December, 2011

Linger RJ, Kruk PA (2010) BRCA1 16 years later: risk-associated BRCA1 mutations and their functional implications. FEBS J 277(15):3086-3096. doi:EJB7735 [pii].10.1111/j.1742-4658.2010.07735.x

Mahfoudh W, Bouaouina N, Ahmed SB, Gabbouj S, Shan J, Mathew R, Uhrhammer N, Bignon YJ, Troudi W, Elgaaied AB, Hassen E, Chouchane L (2011) Hereditary breast cancer in Middle Eastern and North African (MENA) populations: identification of novel, recurrent and founder BRCA1 mutations in the Tunisian population. Mol Biol Rep. doi:10.1007/s11033-011-0829-8

Masri MA, Abdel Seed NM, Fahal AH, Romano M, Baralle F, El Hassam AM, Ibrahim ME (2002) Minor role for BRCA2 (exon11) and p53 (exon 5-9) among Sudanese breast cancer patients. Breast Cancer Res Treat 71(2):145-147

Miki Y, Swensen J, Shattuck-Eidens D, Futreal PA, Harshman K, Tavtigian S, Liu Q, Cochran C, Bennett LM, Ding W et al (1994) A strong candidate for the breast and ovarian cancer susceptibility gene BRCA1. Science 266(5182):66-71

Montagna M, Dalla Palma M, Menin C, Agata S, De Nicolo A, Chieco-Bianchi L, D'Andrea E (2003) Genomic rearrangements account for more than one-third of the BRCA1 mutations in northern Italian breast/ovarian cancer families. Hum Mol Genet 12(9):1055-1061

Oldenburg RA, Meijers-Heijboer H, Cornelisse CJ, Devilee P (2007) Genetic susceptibility for breast cancer: how many more genes to be found? Crit Rev Oncol Hematol 63(2):125-149. doi:S1040-8428(06)00249-6[pii]10.1016/j. critrevonc.2006.12.004

Ozdag H, Tez M, Sayek I, Muslumanoglu M, Tarcan O, Icli F, Ozturk M, Ozcelik T (2000) Germ line BRCA1 and BRCA2 gene mutations in Turkish breast cancer patients. Eur J Cancer 36(16):2076-2082. doi:S0959-8049(00)00277-X[pii]

Stoppa-Lyonnet D, Laurent-Puig P, Essioux L, Pages S, Ithier G, Ligot L, Fourquet A, Salmon RJ, Clough KB, Pouillart P, Bonaiti-Pellie C, Thomas G (1997) BRCA1 sequence variations in 160 individuals referred to a breast/ovarian family cancer clinic. Institut Curie Breast Cancer Group. Am J Hum Genet 60(5):1021-1030

Troudi W, Uhrhammer N, Sibille C, Dahan C, Mahfoudh W, Bouchlaka Souissi C, Jalabert T, Chouchane L, Bignon YJ, Ben Ayed F, Ben Ammar Elgaaied A (2007) Contribution of the BRCA1 and BRCA2 mutations to breast cancer in Tunisia. J Hum Genet 52(11):915-920. doi:10.1007/s10038-007-0195-5

Uhrhammer N, Abdelouahab A, Lafarge L, Feillel V, Ben Dib A, Bignon YJ (2008) BRCA1 mutations in Algerian breast cancer patients: high frequency in young, sporadic cases. Int J Med Sci 5(4):197-202

van der Merwe N, Hamel N, Schneider SR, Apffelstaedt J, Wijnen J, Foulkes W (2010) A founder BRCA2 mutation in non-Afrikaner breast cancer patients of the Western Cape of South Africa. Clin Genet. doi:10.1111/j.1399-0004.2010.01617.x

Whittemore AS, Gong G, Itnyre J (1997) Prevalence and contribution of BRCA1 mutations in breast cancer and ovarian cancer: results from three U.S. 
population-based case-control studies of ovarian cancer. Am J Hum Genet 60(3):496-504

Wooster R, Bignell G, Lancaster J, Swift S, Seal S, Mangion J, Collins N, Gregory S, Gumbs C, Micklem G (1995) Identification of the breast cancer susceptibility gene BRCA2. Nature 378(6559):789-792. doi:10.1038/378789a0

Yawitch TM, van Rensburg EJ, Mertz M, Falkson Cl (2000) Absence of commonly recurring BRCA1 mutations in black South African women with breast cancer. S Afr Med J 90(8):788

Yazici H, Bitisik O, Akisik E, Cabioglu N, Saip P, Muslumanoglu M, Glendon G, Bengisu E, Ozbilen S, Dincer M, Turkmen S, Andrulis IL, Dalay N, Ozcelik H (2000) BRCA1 and BRCA2 mutations in Turkish breast/ovarian families and young breast cancer patients. Br J Cancer 83(6):737-742. doi:10.1054/ bjoc.2000.1332.S0007092000913326[pii]

Zhang B, Fackenthal JD, Niu Q, Huo D, Sveen WE, DeMarco T, Adebamowo CA, Ogundiran T, Olopade OI (2009) Evidence for an ancient BRCA1 mutation in breast cancer patients of Yoruban ancestry. Fam Cancer 8(1):15-22. doi:10.1007/s10689-008-9205-9

Zhang J, Fackenthal JD, Huo D, Zheng Y, Olopade OI (2010) Searching for large genomic rearrangements of the BRCA1 gene in a Nigerian population. Breast Cancer Res Treat 124(2):573-577. doi:10.1007/s10549-010-1006-9

doi:10.1186/2193-1801-1-83

Cite this article as: Oluwagbemiga et al:: Seventeen years after BRCA1:

what is the BRCA mutation status of the breast cancer patients in

Africa? - a systematic review SpringerPlus 2012 1:83.

\section{Submit your manuscript to a SpringerOpen ${ }^{\circ}$ journal and benefit from:}

- Convenient online submission

- Rigorous peer review

- Immediate publication on acceptance

- Open access: articles freely available online

- High visibility within the field

- Retaining the copyright to your article

Submit your next manuscript at $\gg$ springeropen.com 